\title{
Mário e Drummond: nacionalismo, alteridade, arte
}

\author{
SIMONE ROSSINETTI RUFINONI ${ }^{I}$
}

"Brasil que eu sou porque é a minha expressão muito engraçada, Porque é o meu sentimento pachorrento,

Porque é o meu jeito de ganhar dinheiro, de comer e de dormir.”

(Mário de Andrade)

"Nenhum Brasil existe. E acaso existirão os brasileiros?"

(Carlos Drummond de Andrade)

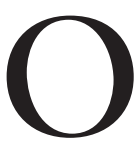

CONTRAPONTO entre a obra de Mário de Andrade e Carlos Drummond de Andrade, dado a lume pela correspondência, bem como pela recorrência de assuntos e temas na poesia de ambos, permite descortinar as continuidades e rupturas entre as duas gerações do modernismo brasileiro. Dentre as tantas convergências e divergências, ressumam os impasses acerca da concepção do nacional, do conflito em torno da individualidade, da alteridade e da concepção de engajamento em arte. Motivos que se entroncam na dialética fundadora do modernismo entre cosmopolitismo e primitivismo, como desdobramentos da condição que os criou: nacionalismo versus internacionalismo, coletivismo versus individualismo e engajamento versus abstencionismo. Os pontos de discussão expostos nas cartas - de onde emergem questões de estética e política, arte e ética, poética e práxis - comparecem estilizados e cifrados na lírica, cuja análise permite entrever o conflito. ${ }^{1}$

Da trajetória empenhada de Mário em busca da identidade nacional - haurida da redescoberta das fontes primevas de nossa arte popular, de par com a urgência em estilizar uma língua nacional, até o desalento diante da constatação da multiplicidade insondável do indivíduo e do ser nacional - são exemplos as muitas máscaras de sua lírica, bem como o destino de Macunaíma que, cifrado em constelação, é signo da petrificação de um projeto cuja riqueza residiria paradoxalmente na sua impossibilidade. Aquele cuja trajetória funde estética e ética não poderia aceitar a postura aparentemente antinacionalista com a qual o poeta mineiro encarava as coisas de seu país. O universalismo drummondiano deveria ter passado pelas etapas de construção da nacionalidade, sem as quais um poeta num país periférico não tem direito ao canto. Essa a percepção de Mário para quem a arte interessada era uma necessidade angustiante, uma etapa a ser superada. A ultrapassagem do momento nacional se daria, porém, pela conquista de um coletivismo já inconscientemente nacional que não se confundiria com 
um individualismo tendente ao abstencionismo. É assim que o entrelaçamento de cosmopolitismo e primitivismo, eixo da problemática modernista, é tematizado pelas cartas sob a óptica do nacionalismo cuja ausência foi condenada pelo mestre. Esse par de missivas do ano 1924 dá a ver o debate. Assim se posiciona Drummond a respeito da questão do nacional:

Reconheço alguns defeitos que aponta no meu espírito. Não sou ainda suficientemente brasileiro. Mas, às vezes, me pergunto se vale a pena sê-lo. Pessoalmente, acho lastimável essa história de nascer entre paisagens incultas e sob céus pouco civilizados. Tenho uma estima bem medíocre pelo panorama brasileiro. Sou um mau cidadão, confesso. É que nasci em Minas, quando devera nascer (não veja cabotinismo nesta confissão, peço-lhe!) em Paris. O meio em que vivo me é estranho: sou um exilado. $\mathrm{E}$ isto não acontece comigo, apenas: "Eu sou um exilado, tu és um exilado, ele é um exilado". Sabe de uma coisa? Acho o Brasil infecto. Perdoe o desabafo, que a você, inteligência clara, não causará escândalo. $O$ Brasil não tem atmosfera mental; não tem literatura; não tem arte; tem apenas uns políticos muito vagabundos e razoavelmente imbecis ou velhacos. Entretanto, como não sou nem melhor nem pior do que os meus semelhantes, eu me interesso pelo Brasil. Daí o aplaudir com a maior sinceridade do mundo a feição que tomou o movimento modernista nacional, nos últimos tempos: feição francamente construtora, após a fase inicial e lógica dos falsos valores. (Santiago, 2002, p.56, carta de 22 de novembro de 1924)

O poeta segue expondo os motivos pelos quais se considera "acidentalmente brasileiro" já que o panorama local seria "nocivo à expansão de meu espírito". E arremata seu pensamento num trecho decisivo em que a oposição nacionalismo versus internacionalismo comparece com excessiva sinceridade no tom de desabafo que o oporá frontalmente a Mário:

E por outro lado, estou quase a afirmar que uma certa classe de espíritos, de formação e educação nitidamente universalistas, tem solene direito de sobrepor as suas conveniências mentais às dessa mesma confusa e anônima cambada de bestas. Monstruoso? Será antes humano. Espero que não veja nessas palavras a intenção de criar uma oligarquia intelectual, ou qualquer coisa parecida com um clã ou um mandarinato das letras. Não. Estamos, se não me engano, em dias largamente democráticos, em que nenhuma aristocracia é possível, mesmo a da inteligência. Quis apenas justificar a posição em que se encontram muitas criaturas honestas, inteligentes e cultas, em face de apertado dilema: nacionalismo ou universalismo. $\mathrm{O}$ nacionalismo convém às massas, o universalismo convém às elites (repito: não se trata de clã). (ibidem, p.60)

A esse trecho Mário retruca:

Tudo errado. Primeiro não existe essa oposição entre nacionalismo e universalismo. O que há é mau nacionalismo: o Brasil para brasileiros - ou regionalismo exótico. Nacionalismo quer simplesmente dizer: ser nacional. O que mais simplesmente significa: Ser. Ninguém que seja verdadeiramente, isto é, viva, se relacione com o seu passado, com as suas necessidades imediatas prá- 
ticas e espirituais, se relacione com o meio e com a terra, com a família etc., ninguém que seja verdadeiramente deixará de ser nacional. O despaisamento provocado pela educação em livros estrangeiros, contaminação de costumes estrangeiros por causa da ingênita macaqueação que existe sempre nos seres primitivos, ainda, por causa da leitura demasiadamente pormenorizada não das obras-primas universais dum outro povo, mas das suas obras menores, particulares, nacionais, esse despaisamento é mais ou menos fatal, não há dúvida, num país primitivo e de pequena tradição como o nosso. Pois é preciso desprimitivar o país, acentuar a tradição, prolongá-la, engrandecê-la. (ibidem, p.70)

Caberia ao brasileiro aperfeiçoar a sua civilização que no momento não passa de imitação. A reivindicação de Mário é a do abrasileiramento necessário ao homem integral que possa auxiliar a emancipação cultural da nação. Na mesma carta, define o sentido de uma raça como um "acorde", espécie de feixe de atributos psicológicos que lembra o poema de Clã do jabuti, "O poeta come amendoim", cujo percurso dá conta de um sentido utópico do modo de ser brasileiro. A postura ética do intelectual brasileiro casa-se à apreensão desse outro cujo ethos nacional é parte de uma coletividade. Em outro registro, a análise do poema carreia sentido à discussão. Leia-se o poema:

\section{O POETA COME AMENDOIM}

Noites pesadas de cheiros e calores amontoados...

Foi o sol que por todo o sítio do Brasil

Andou marcando de moreno os brasileiros.

Estou pensando nos tempos de antes de eu nascer...

A noite era pra descansar. As gargalhadas brancas dos mulatos...

Silêncio! O imperador medita os seus versinhos.

Os Caramurus conspiram à sombra das mangueiras ovais.

Só o murmurejo dos cre'm-deus-padre irmanava os homens de meu país...

Duma feita os canhamboras perceberam que não tinha mais escravos,

Por causa disso muita virgem-do-rosário se perdeu...

Porém o desastre verdadeiro foi embonecar esta República temporã.

A gente inda não sabia se governar...

Progredir, progredimos um tiquinho

Que o progresso também é uma fatalidade...

Será o que Nosso Senhor quiser!...

Estou com desejos de desastres...

Com desejo do Amazonas e dos ventos muriçocas

Se encostando na canjerana dos batentes...

Tenho desejos de violas e solidões sem sentido...

Tenho desejos de gemer e de morrer... 
Brasil...

Mastigado na gostosura quente do amendoim...

Falado numa língua curumim

De palavras incertas num remeleixo melado melancólico...

Saem lentas frescas trituradas pelos meus dentes bons...

Molham meus beiços que dão beijos alastrados

E depois remurmuram sem malícia as rezas bem nascidas...

Brasil amado não porque seja minha pátria,

Pátria é acaso de migrações e do pão-nosso onde Deus der...

Brasil que eu amo porque é o ritmo no meu braço aventuroso,

O gosto dos meus descansos,

O balanço das minhas cantigas amores e danças.

Brasil que eu sou porque é a minha expressão muito engraçada,

Porque é o meu sentimento pachorrento,

Porque é o meu jeito de ganhar dinheiro, de comer e de dormir.

Valendo-se do arsenal mítico-mágico, Mário emula o modo arcaico, ao ancorar a gênese do povo brasileiro no mito: algo como a cópula entre o dia e a noite que, prenhe de "cheiros e calores", dará luz ao povo de tez morena. Não se vê paródia na utilização do mito, mas sim sua estilização, na articulação do erudito com o popular. O olhar moderno fica por conta desse "eu" que se imiscui no canto coletivo e do tom algo sarcástico, não porém demolidor, com que se enunciam traços da história nacional.

Acumulam-se imagens do Brasil, da colônia à República. O “murmurejo do cre'm-deus-padre", aludindo à oração cristã entoada servilmente pelos nativos, traz à tona a catequese; já em "os canhamboras perceberam que não havia mais escravos" vislumbra-se a abolição. Percebe-se o tom irônico que, contudo, à moda pau-brasil, se compraz na constatação de um modo de ser. Ao final da estrofe com o verso: "Será o que Deus Nosso Senhor quiser!..." ouve-se o dialogismo da fala popular desprovida de cálculo ou criticidade, na aceitação da providência divina como desdobramento de uma fatalidade; a resignação aqui identificada como modo de ser encampará o germe da "paciência" identificada no totem do boi.

Do amálgama composto por alimento, língua, religiosidade e sensualidade emerge, antropofagicamente, uma imagem culturalmente sensória da nação; todos elementos triturados pelos bons dentes daquele que persegue um modo de ser uno, paradoxo da síntese em meio à multiplicidade - acorde, como queria Mário. A caracterização metafórica e sensorial conta com o recurso intenso da sonoridade nasalada e sibilante, instila o erotismo que se cinge à cordialidade, inatividade e indolência, farpas dos tantos traços que o caráter nacional colecionou. No processo metonímico, o Brasil é comido e falado, as palavras assemelham-se ao amendoim. A língua “curumim” gera prazer que, da saciedade, se comunica ao sentido algo sensualizado do modo de ser nacional. 
O curso da análise revela que a caracterização do país ancora-se nos sentidos que assumem configurações diversas passando do alimento à sexualidade. Assim é que se pode ler o verso: "De palavras incertas num remeleixo, melado melancólico...". A associação de imagens: a dança ou ginga (remeleixo) atrelada à meiguice ou ternura (melado) por sua vez retornam à metáfora do alimento misturado à tristeza e à indolência aproximando-se da caracterização do brasileiro como povo melancólico. Síntese que alude à valorização da preguiça, do ócio como parte constitutiva do modo de ser nacional. O verso contém uma sonoridade que mimetiza o ritmo de um movimento lento e constante, embebido em tonalidades eróticas. O efeito é obtido pela repetição da sonoridade nasal: “...iNcertas NuM reMeleixo Melado MelaNcólico" que, aliado à inexistência de vírgulas, é responsável pela ilusão de simultaneidade. Remete também ao último verso da estrofe anterior: "Tenho desejos de gemer e de morrer", na coexistência do prazer a certa tendência de aniquilação. Desponta novamente a presença da melancolia que, somada à luxúria, remete a Paulo Prado, não por acaso aquele a quem o autor dedica Macunaima. Notam-se, ainda, inflexões que antecipam o pensamento de Gilberto Freyre uma vez que à peculiar tristeza acrescenta-se a indolência, traço do caráter que remete às considerações do sociólogo sobre a impossibilidade de o índio aceitar o trabalho organizado, dada a sua atividade voltada à subsistência. Assim, a figuração do caráter nacional contrabalança o peso negativo da visão de Paulo Prado por meio da síntese poética e ideológica das singularidades culturais da nação (alimento, dança, religiosidade, sexualidade).

A sonoridade com forte apelo sibilante e nasal consegue efeito sensualmente sugestivo: "Saem lentas frescas trituradas pelos meus dentes bons/ Molham meus beiços que dão beijos alastrados". O amendoim participa da metáfora da nação e remete ao sentido de alimento, ao mesmo tempo, nativo e afrodisíaco. $\mathrm{Na}$ sétima estrofe, percebe-se o sentido específico desse nacionalismo: o que se revela poeticamente é um Brasil que vale não por ser a pátria, mas sim por configurar um modo de ser, um caráter. Ao final, a identificação do país com o eu lírico - "Brasil que eu sou [...]", "Porque é o meu sentimento [...]", "Porque é o meu jeito [...]" (grifos meus) - expressa o nó entre individualismo e coletividade: busca da identidade nacional que se comunica à da identidade pessoal.

Tem-se a imagem de um país totêmico: Brasil da selva, dos mitos, dos acalantos. Longe do progresso, perto da preguiça na necessidade de fecundar uma "civilização primitiva". Canto de um modo de ser livre e autêntico, primitivo, cuja harmonia ressalta um país mestiço e sincrético. A imagem que se cunha é a de um povo voltado à criatividade, à sensualidade cuja origem o afasta das tarefas laboriosas. O resultado é a positividade do modo de ser brasileiro sem constatação da barbárie do processo colonizador ou da gravidade do conflito de classes. A suspensão do conflito em nome da identidade mítica tem por resultado um eu íntegro, diferente do eu dilacerado que será a tônica em sua lírica posterior. Sabe-se que, a partir de meados dos anos 1930, a percepção do conflito social entrelaça-se à fragmentação do eu, eclodindo em imagens de crise, desconforto e automutilação. ${ }^{2}$ 
O contraponto negativo a essa comovedora, e possivelmente ingênua, busca de Mário encontra-se em "Hino Nacional” de Drummond, poema de Brejo da almas (1934). Elaboração estética do mal-estar testemunhado pelas cartas, a amargura da confissão é compensada pela frieza da meditação irônica. Em tom de blague, o poeta enuncia, no primeiro verso das estrofes $1^{\mathrm{a}}, 3^{\mathrm{a}}, 5^{\mathrm{a}}, 6^{\mathrm{a}}$ e $7^{\mathrm{a}}$, tudo o que é preciso fazer pela pátria: "Precisamos descobrir o Brasil" / "Precisamos educar o Brasil" / "Precisamos louvar o Brasil" / "Precisamos adorar o Brasil!" - e, por último, "Precisamos, precisamos esquecer o Brasil!". Pelo recurso da anáfora, acumulam-se referências às belezas naturais do país indevassado. Ouve-se o eco das reivindicações da vanguarda brasileira, que remonta aos românticos, no apego à ideia de país autêntico, enquanto o eco do discurso às massas encampa a voz autoritária e patriarcal que insufla a positividade escamoteadora da ordem social. Segue-se uma série de providências civilizadas, ironicamente arroladas como etapas na consolidação desse país; devem-se importar mulheres, eletrodomésticos, benfeitorias, educação. No seguimento da anáfora, a estilização do dialogismo demagógico refaz as palavras de ordem do ideal de progresso (descobrir, educar, louvar, adorar) e o tom apologético segue desmentido pela ironia que emerge da paródia, escancarando o despropósito das reivindicações. Não há como esquecer as lições de Mário, aqui contrapostas a uma nova dicção permeada de desconsolo e desilusão. Para além da década que separa os poemas, medeia-os a diferença entre visões de país e projetos artísticos. O poema é arrematado pela estrofe:

Precisamos, precisamos esquecer o Brasil!

Tão majestoso, tão sem limites, tão despropositado,

Ele quer repousar de nossos terríveis carinhos.

O Brasil não nos quer! Está farto de nós!

Nosso Brasil é no outro mundo. Este não é o Brasil.

Nenhum Brasil existe. E acaso existirão os brasileiros?

Não por acaso, o momento da desconstrução das proposições anteriores conta com o vocativo anafórico duplicado. Denuncia-se a ideologia que sustém a ideia de pátria ou de caráter nacional: as boas intenções não bastam, há algo de equívoco e falso na busca pela totalidade. Assim, Brasil, ou nação, e brasileiros são abstrações que camuflam conflitos reais. É como se lêssemos o desfazimento do processo edificante, demolição que parece sussurrar “é preciso criticar o (ou o que se fez do) Brasil".

A aproximação dos dois poemas permite vislumbrar um páthos diverso no que respeita ao entendimento da ideia de nação, cujo desdobramento identitário culmina na plasmação de certa subjetividade que conteria as marcas desse ser nacional. O modo de ser "melado e melancólico", que reúne sexualidade, indolência, resignação e cordialidade, só pode constituir-se amenizando os traços da violência inerentes à nossa formação. A figuração obtida não condiz com o olhar de Drummond para quem paira sobre a nação e o sujeito brasileiro dúvidas que culminam no despaisamento e na desindividuação. 
De modo oblíquo, percebe-se que também para Drummond a nação se oferece como assunto relevante, menos locus de identidade e mais espaço epistemológico cuja construção desmorona diante da investigação dos sentidos históricos que a erigiram. $\mathrm{O}$ argumento iconoclasta fará ruir, entoado pela derrisão da voz enunciadora, a coletividade calcada em um modo de ser. Homem e nação sujeitam-se à erosão do primado inespecífico com o qual a poética drummondiana lida, adentrando o terreno palmilhado pelo debate em torno da noção de coletividade.

Pode-se, ainda, surpreender o diálogo com o Mário de "Dois poemas acreanos", cujo tom paternalista associa a figura do seringueiro ao brasileiro, encarnação da potencialidade do homem nacional que, como a nação, dorme. Assim como o seringueiro, o país, apto a ser descoberto, ainda não despertou. Cabe ao artista auxiliá-lo nessa tarefa. Em Drummond, o uso da ironia põe em xeque o idealismo do mestre: "O Brasil está dormindo, coitado/ Precisamos colonizar o Brasil".

O percurso da discussão sobre o nacionalismo desdobra-se no dilema individualismo versus coletivismo. A correspondência é fecunda em exemplos. Posiciona-se Mário sobre Alguma poesia:

Seu livro é excessivamente individualista. Há uma exasperação egocêntrica enorme nele. Está claro que isso não diminui em nada os valores do seu lirismo. Diminuem a meu ver os valores edificantes utilitários de sua poesia. Você e o Manuel se equiparam inteiramente nisso. A sociedade, a humanidade, a nacionalidade funcionam pra vocês em relação a vocês e não vocês em relação a elas [...] (Santiago, 2002, p.386, carta de $1^{\circ}$ de julho de 1930)

A exigência é explicada em carta anterior, quando reflete sobre o que desejava para sua própria poesia:

[...] expliquei a parte que me interessava no caso, do que chamei, por falta de substantivo, de apelo de humanidade. Desejo de me igualar me desindividualizar, despersonalizar, não para ser clássico (preocupação que hoje considero besta tanto como ser romântico) porém para me dar como lirismo de que todos participem e não como espetáculo.

[...]. Minha revolta de Pauliceia, embora alguns tenham sentido também revoltas, não saiu universalizável, é um grito dum homem só, grito meu inconfundível. Ora hoje eu quero gritar de tal forma que meu grito seja o de toda a gente. Quero dizer, tornar o menos pessoal possível minhas coisas para que se tornem gerais [...] (ibidem, p.260, carta de 23 de novembro de 1926)

Trata-se do esforço em desindividualizar sua obra, desbastá-la da presença do eu, tornando-a socializável. O empenho, contudo, traz prejuízos à expressão lírica segundo Drummond. Para este, há poemas do mestre que são pouco líricos e muito prosaicos, discursivos, como se o assunto desbordasse os limites do gênero. Nas palavras do poeta mineiro:

Você me parece ceder por vezes à ânsia de comunicar coisas urgentes que estão se passando no seu íntimo e que não são propriamente poesia. Coisas 
que dariam provavelmente um discurso... Em suma, você é muito universal demais para ser apenas poeta e há porções respeitáveis do seu ser que reagem contra a poesia no instante mesmo em que ela está se elaborando. Eu considero a poesia uma limitação, boa ou má não vem ao caso, e a linguagem em que é menos fácil aos homens se comunicarem, porque é a linguagem que poucos falam e mesmo esses não a possuem permanentemente. E você, alma apostólica (perdoe o adjetivo pois não acho outro), coração numerosíssimo e transbordante de humana ternura, tem tanto que comunicar aos outros! É natural que sua linguagem seja às vezes um pouco turva e inquieta $[\ldots]$ (ibidem, p.401, carta de $1^{\circ}$ de janeiro de 1931)

De modos diversos, premia a ambos a consciência do impasse da individualidade na expressão lírica em face do imperativo da temática social. Por um lado, Mário chega a dizer em outra carta: "você se lembra duma vez em que falei pra você que não fazia mais arte porque minhas obras eram demasiadamente interessadas pra ser arte. Tenho sempre essa impressão" (ibidem, p.150, carta de 16 de outubro de 1925). Por outro lado, Drummond sentia-se desconfortável diante de seu individualismo:

Eu confesso que não consigo evadir-me do meu individualismo para vogar nessas paragens largas e povoadas para as quais me solicitam as tendências intelectuais do meu tempo, e por outro lado ainda não cheguei (e chegarei algum dia?) à maturação necessária para tentar a solução supra-realista, única que me parece aceitável no meu caso, como de resto para todos os casos. (ibidem, p.401, carta de $1^{\circ}$ de janeiro de 1931)

Quando Mario (1974, p.254) identifica e ajuíza o excessivo individualismo do amigo, há que lembrar da autoacusação presente em "O movimento modernista" que se insere no contexto da arte engajada versus arte desinteressada cujo arremate desemboca no conhecido e dilacerador mea culpa: "tendo deformado toda a minha obra por um anti-individualismo dirigido e voluntarioso, toda a minha obra não é mais que um hiperindividualismo implacável!". O clamor é pela necessidade de conteúdos participativos que, não obstante, e pela sua própria natureza, ameaçam deformar a arte. Acentua-se a angústia pela constatação de que a arte brasileira, no momento em questão, ainda não tem direito à almejada liberdade do universal, comprometida que está com o processo formativo do país. Como se as condições de país periférico toldassem a finalidade sem fim, própria da condição artística. Nesse sentido, nota-se que a lírica social de Drummond dará outra resposta à urgência do engajamento; a crise do sujeito individualizado, contudo, não se resolve, retorna reposta sob outras bases que não deixam de conter a oposição entre aristocratismo e coletividade.

Com a publicação de Sentimento do mundo, em 1940, Mário reconhece o coletivismo de Drummond e o parabeniza. Nesse sentido, mesmo que ambos, de algum modo, se coletivizem, os caminhos e os impasses diante do processo de desindividuação falam sobre experiências que têm suas particularidades. Leia-se trecho da carta onde acorrem fragmentos de crítica a Sentimento do mundo: 
Sentimento do mundo é o resultado de um poeta verdadeiro cuja vida se transformou. O poeta não mudou, é o mesmo, mas as vicissitudes de sua vida, novos contatos e contágios, novas experiências, lhe acrescentaram ao ser agressivo, revoltado, acuado em seu individualismo irredutível, uma grandeza nova, o sofrimento pelos homens, o sentimento do mundo. Foi realmente um acrescentamento enorme, esse juntar às dores do indivíduo, a fecundidade da dor humana, e se já dantes o poeta tímido que apelidava um livro de "alguma poesia” já era um grande poeta agora que conscientemente apelidou seus novos versos com o título orgulhoso de Sentimento do mundo, nos deu uma obra que além de grande é extraordinária. Individualismo irredutível de Alguma poesia. Em Sentimento do mundo o poeta sem nada perder do seu individualismo, além da dor do indivíduo, dentro dela, junto com ela, sofre da humana dor. (Santiago, 2002, p.483, carta de 15 de agosto de 1942)

À problemática do nacionalismo, compreendido como parte da dialética do local e do universal, se entronca a da formação do sujeito histórico brasileiro, paradoxo que, por sua vez, tomaria a forma da oscilação individualismo versus coletivismo, recorrente, sob formas diversas, na obra de ambos. Podem-se percorrer traços dessa temática pela via de poemas que abordam o outro ora sob a égide de um modo de ser, ora sob outra óptica: a da diferença de classes, do anonimato e da condição cindida do sujeito moderno. Veja-se, a esse título, o caso dos poemas "Cabo Machado" e "O poeta come amendoim": em ambos ocorre um outro marcadamente local, não segundo algum estereótipo mal traçado, mas numa coexistência de sensibilidade e ethos: gesto, cor, paladar, sexualidade, comportamentos que permitiriam apreender certa identidade - reencenação do “acorde" apto a traduzir o caráter nacional.

A afirmação de Mário acerca do "individualismo irredutível” de Alguma poesia, que resistiria com nova inflexão em Sentimento do mundo, talvez contivesse a percepção ainda tateante de um caminho que conduziria o poeta mineiro à identificação da diferença decisiva, conduzindo à substituição do dilema internacional versus local pelo conflito de classes.

Desse modo, em face da recepção sobre a lírica social de Drummond, é possível entrever como o impasse acerca do individualismo ou da coletividade incide sobre outra dobra da questão: a difícil figuração da alteridade. As inflexões do sujeito lírico ante a nação e o outro lançam luzes também sobre a segunda fase da lírica de Mário (do "poeta aplicado”), possibilitando o contraste entre as duas gerações. ${ }^{3}$ É o que se pode inferir - sem desprezar a diferença de datas, ao contrário reforçando nesse hiato o caráter datado das abordagens - da comparação entre "Os dois poemas acreanos", de Clã do jabuti, e "O operário no mar", poema em prosa de Sentimento do mundo. Seja o seringueiro do norte, seja o operário, ambos figuram o outro em face do intelectual: o homem do povo, o homem simples. A eles o poeta se volta, para eles endereça seu canto, o mesmo impulso os une uma vez que desejam desprender-se de sua condição de classe, ser o outro, estar com o outro, solidarizar-se. A relação entre o eu 
distante, poeta e classe média, desse outro quase abstrato de tão desconhecido traz convergências: a voz que enuncia sabe-se apartada, reconhece, chama e ama esse irmão que, contudo, se fecha em copas, enigma que é cifra da incomunicabilidade de classe. No entanto, malgrado a boa-fé em comum, as diferenças saltam à vista; ao eu lírico que se aproxima do seringueiro de modo camarada e complacente corresponde o burguês irremediavelmente distante do trabalhador braçal, visto como um deus em sua luta social. Observe-se o primeiro "Poema acreano", seguido de trecho de "O operário no mar":

\section{DESCOBRIMENTO}

Abancado à escrivaninha em São Paulo

$\mathrm{Na}$ minha casa da Rua Lopes Chaves

De sopetão senti um friúme por dentro.

Fiquei trêmulo, muito comovido

Com o livro palerma olhando pra mim.

Não vê que me lembrei lá no norte, meu Deus! Muito longe de mim,

$\mathrm{Na}$ escuridão ativa da noite que caiu,

Um homem pálido, magro de cabelo escorrendo nos olhos

Depois de fazer uma pele com a borracha do dia,

Faz pouco se deitou, está dormindo.

Esse homem é brasileiro que nem eu...

$[\ldots]$

Para onde vai o operário? Teria vergonha de chamá-lo meu irmão.

Ele sabe que não é, nunca foi meu irmão, que não nos entenderemos nunca.

E me despreza... ou talvez seja eu próprio que me despreze a seus olhos.

Em ambos a voz lírica confronta-se com a alteridade: desejam a aproximação, assumem-se ignorantes frente a essa outra realidade e concebem o outro como indiferente a seus apelos. Mário:

$[\ldots]$

Companheiro, dorme!

Porém nunca nos olhamos

Nem ouvimos e nem nunca

Nos ouviremos jamais...

Não sabemos nada um do outro,

Não nos veremos jamais!

Seringueiro, eu não sei nada! 
$[\ldots]$

Nem você pode pensar

Que algum outro brasileiro

Que seja poeta no sul

Ande se preocupando

Com o seringueiro dormindo

Desejando pro que dorme

O bem da felicidade...

Essas coisas pra você

Devem ser indiferentes,

Duma indiferença enorme

Porém eu sou seu amigo

E quero ver si consigo

Não passar na sua vida

Numa indiferença enorme [...]

Canto que converge para o de Drummond em: "Para onde ele vai pisando assim tão firme? Não sei". Contudo, a indagação final: "quem sabe se um dia o compreenderei?", apesar de se abrir para uma promessa de comunhão no horizonte da luta social, não prescinde do abismo da distância entre eu e o outro enunciado pela imagem sublime do operário que caminha sobre as águas da história, simbolicamente partidas para sua passagem. Em Mário, a intenção do "amor-de-amigo enorme" é suficiente promessa de felicidade; o poeta acalenta o sono inconsciente do homem do povo que, para além das diferenças, é brasileiro como ele.

Flagram-se dois modos de conceber o outro: a distância suprimida pela comoção da identidade, a distância ampliada pela constatação do conflito. A angústia diante do operário é consequência da maturidade advinda da "consciência catastrófica de atraso" de que nos fala Antonio Candido, detectada como diferencial entre a primeira e a segunda gerações do modernismo brasileiro; apesar da ânsia de aproximação, testemunhada inclusive pela carga de idealização que subjaz à figura do trabalhador, a divisão de classes aparta os homens, indissoluvelmente. O cuidado para com o outro o tornará parte do impasse no qual o eu lírico sente-se enredado, conduzindo ao sentimento cada vez mais inescapável da limitação do eu poeta a ponto do lugar de fala ser encarado como problema. A consciência acusará a impotência do artista engajado nas causas do seu tempo, seu modo de inserção social se fará, em grande parte, da dolorosa percepção de como a lírica é instrumento frágil e inoperante diante dos males do mundo.

Para além da circunstância incontornável da diferença de classe, a outra face do operário ressoa a do outro anônimo, fragmentado e kafkiano do famoso poema "José". Sujeito negativo e cindido, universal e nacional, cujo traçado polifônico aproveita sutis pormenores locais de par com a apreensão da condição desalentadora do homem moderno. O processo de esvaziamento da individualidade é acrescido da interdição de qualquer ato, a ironia que sela a perda de rota é signo de descentramento e petrificação: José reúne o eu e o outro, irmanados na 
alienação e impotência. Tais contrapontos pessimistas ao altruísmo mariodeandradiano ganham relevo se confrontados aos poemas já mencionados "O poeta come amendoim" e "Cabo Machado", ambos figurações do caráter nacional.

Cumpre dizer, no entanto, que a impiedosa matéria do mundo recairia também sobre a obra do mestre. As fases de sua lírica atestam a passagem do idealismo à constatação dos impasses. Sua obra também sofrerá os dramas dos anos 1930 com o acirramento da luta social e a emergência da noção de subdesenvolvimento. As figurações dos modos de ser nacionais (como Cabo Machado ou o seringueiro) darão lugar a apreensões poéticas minadas pelo despedaçamento; momento do sparagmós, de acordo com Lafetá (1986, p.38-46), que apontou em sua obra a presença das etapas do mito arcaico de morte e ressurreição. A recognição mítica, anagnórisis, cuja inflexão assume parentesco com a busca pela autenticidade cultural, contudo, cada vez mais se mostrará inalcançável, promovendo a substituição da euforia pela perplexidade. Mais apartada do entusiasmo de primeira hora, a lírica do poeta mineiro já nasce torta: faz da desconfiança e da inadequação seus modos de inserção no mundo.

Por caminhos transversos, é possível reconhecer um drama comum aos dois poetas. Percebem, cada um a seu modo, e com a agudeza que a expressão poética permite, o descompasso entre a voz lírica, instrumento da palavra poética como arma capaz de dirimir o abismo entre o intelectual e o povo, e a ação potencialmente transformadora. Na obra do poeta paulistano, é da busca pela identidade de si e do outro que reponta o drama da impossível unidade em meio à avassaladora multiplicidade - do país, do outro e do eu. Sabe-se, como ensinou Anatol Rosenfeld (1973), da intensa e cívica luta de Mário pela síntese, cujo sentido mais fundo toca a pureza e a autenticidade caras à identidade nacional, esforço que esbarrou na natureza necessariamente artificial da arte, a ponto de o autor produzir uma teoria nobilitadora a respeito das máscaras. ${ }^{4}$ Por trás dessa busca incessante e dilaceradora está a quimera de atingir a totalidade perdida, cujos caminhos atendem pelos nomes de arte interessada, identidade nacional ou estilização da língua brasileira.

Da dialética da alteridade participa determinada postura do intelectual diante do papel da arte na sociedade. Um par de cartas do ano de 1929 oferece o contraste entre dois modos de encarar a luta e o fracasso da arte e do artista em face da hostilidade do mundo. A eles pode-se acrescentar a reflexão sobre a torre de marfim, como lugar simbólico da isenção ou da resistência. De certo modo, há nessas páginas modos diferentes de conceber a ideia de engajamento que, no caso de Drummond, culminará no aparente descolamento do mundo expresso pela conhecida epígrafe de Paul Valéry, a Claro enigma: les événements m'ennuient.

Nesse contexto, diz Mário a Drummond:

[...] Já sei que você é folha ao atá, levada pelos ventos. O engraçado é que se trata duma folha pensante, reagente como sensibilidade, que espiritualmente 
caminha contra os ventos mas que até já está achando um certo sabor nessa malinconia de se deixar levar. Porque apesar de todas as reações e projetos e desejos, você continua folha. Você jamais esquecerá que no meio do caminho tinha uma pedra. De primeiro você me comovia, o jeito de você me esfolava o jeito meu, somos fundamentalmente diferentes na maneira de ser. Isto é, de ser, não, porque a base de nós dois é a mesma timidez, mistura dos efeitos da época com o nosso no-meio-do-caminho-tinha-uma-pedra provinciano. $\mathrm{O}$ que temos de diferente foi o meio de praticar a diferença diante da vida. Você como que se esquivou à jogatina. Eu joguei tudo numa cartada só. Estou desconfiando que perdi, não sei. Porém como sou leal para com os jogos, se perder, reconheço que perdi e continuo verdadeiro porque perder nunca foi desdouro para ninguém. Vergonha é falcatruar e eu não faço isso. Você, com que melancolia invejosa falo isso!... você só tem a ganhar em não ter jogado. (Santiago, 2002, p.350, carta de 19 de maio de 1929)

A carta não agrada ao poeta mineiro que assim se pronuncia:

[...] E que ironia você terá posto na "melancolia invejosa" com que olha para a minha não opção? Como se eu também não tivesse jogado... como se até não fosse mais triste fazer o jogo cético que eu fiz, em que nunca tive esperanças e certezas para me abastecer, e sabia previamente que perderia. Eu também quero ter a honra de declarar que perdi o jogo. (ibidem, p.351)

O cotejo dos fragmentos revela a diferença entre o projeto estético-social de Mário e a postura cética de Drummond: para o primeiro o ceticismo confunde-se com abstencionismo; para o segundo toda não opção implica uma opção, e esta, quer pela carga de empenho intelectual que comporta, quer pela desilusão enraizada na práxis, é também vincada pela luta. Diante desses dois modos de conceber a noção de engajamento do artista, figurados em termos de participação ou recusa, repõe-se a problemática do aristocratismo individualista próprio da atividade artística ante a desindividuação com vistas à solidariedade de classes. Ambos sentem na pele o drama da expressão do eu na iminência de falar do outro, para os dois valem as palavras de Antonio Candido (1995, p.112) sobre Drummond: "se aborda o ser, imediatamente lhe ocorre que seria mais válido tratar do mundo; se aborda o mundo, que melhor fora limitar-se ao modo de ser".

Em carta do ano 1945, período em que o mito da unidade do "caráter nacional" já havia sido substituído pela constatação da irremediável cisão do homem e do mundo, Mário finalmente considera a complexidade desse conflito em outros termos:

Pela primeira vez se impôs a mim o meu, o nosso destino de artistas: a Torre de Marfim. Eu sou um torre-de-marfim e só posso e devo ser legitimamente um torre-de-marfim. Só um anjo da guarda perfeito me impediu de escrever um artigo sobre isso no dia em que descobri que sou torre-de-marfim. Mas sobrou o anjo da guarda, felizmente, imagine o confusionismo que isso ia dar e o aproveitamento dos f-da-puta. Porque, está claro, a torre-de-marfim não quer nem pode significar não-se-importismo e arte-purismo. Mas o intelectual, o artista, pela natureza, pela sua definição mesma de não-conformista, 
não pode perder a sua profissão, se duplicando na profissão de político. Ele pensa, meu Deus! E a sua verdade é irrecusável pra ele. Qualquer concessão interessada pra ele, pra sua posição política, o desmoraliza, e qualquer combinação, qualquer concessão o infama. É da sua torre de marfim que ele deve combater, jogar desde o cuspe até o raio de Júpiter incendiando cidades. Mas da sua torre. (Santiago, 2002, p.359, carta de 11 de fevereiro de 1945)

O lugar do intelectual é o do recolhimento crítico, a reflexão não condiz com a ação política. Outros, portanto, são os caminhos da luta para o artista. É como se Mário, nesse trecho tão próximo do fim de sua empenhada existência, compreendesse que a imersão na práxis semelhasse uma faca de dois gumes: a arte que se quer vida tem de se haver, necessariamente, com o mundo deteriorado. Sua constatação final é fruto de um paradoxo: cumpre retomar a categoria da autonomia da arte, espaço do desinteresse, onde a resistência tem lugar. ${ }^{5}$ Essa constatação mais dialética mitiga o mea culpa presente em "O movimento modernista", texto de 1942, e o aproxima de Drummond.

Curioso notar que ambos almejam certa desindividuação - percurso de neutralização do eu a bem da voz coletiva. No entanto, pode gerar certa confusão o fato de Mário acusar a ausência de nacionalismo diante do suposto universalismo drummondiano e, ao mesmo tempo, almejar a comunhão com certo ideal de humanidade, o que, de certa forma, conduziria também a um universalismo. Nesse sentido, há que precisar: o universalismo condenado é tomado em termos de oposição ao nacionalismo e o universalismo desejado é o contraponto à individualidade. De modo que esse segundo universalismo é coletivismo e desindividuação do eu autobiográfico, burguês e "torre de marfim" rumo à perda no grito coletivo. Ambos anseiam, pois, a desindividuação que, no caso da lírica, gera angústia dada a natureza eminentemente subjetiva do gênero; há, contudo, diferenças notáveis que radicam, no limite, na oposição entre a inevitável e negativa despersonalização da sociedade estratificada e a despersonalização pretensamente positiva da indistinção mítica. Em Drummond, regendo o impasse do estatuto da conquista da coletivização está a negatividade e o paradoxo. Como pressuposto à condição do gauche e do mundo caduco a unidade soa falsa, de vez que não se apagam sem mais as marcas de classe; resta à solidariedade dar-se sob o signo do anonimato e da alienação, como se todos se irmanassem diante do incontornável desconhecimento de si. Para o poeta paulistano, a conquista da comunhão com o outro, "brasileiro que nem eu", inseriu-se em um projeto que teve como pano de fundo a arte popular, donde a ancoragem nos modos do mito, que o levaram à ânsia da perda na substância anônima do mundo arcaico. Correndo o risco das restrições sintéticas: a desindividuação pretende situar-se, em um caso, aquém da experiência burguesa; noutro, lhe é contemporânea, reside no fracasso moderno do estatuto do sujeito autônomo. Com efeito, dando voz ao processo moderno de crise do sujeito, Drummond tem razão em reivindicar para si também a honra da perda. Se o retorno aos arquétipos já foi reconhecido como rota de fuga da crise da individualidade burguesa e, desse modo, 
portanto, está disseminado na experiência moderna, em Mário parece ser outro o sentido do retorno, aquém da fragmentação do homem, daí a medida da altura de sua utopia e, consequentemente, de sua queda. ${ }^{6}$

Cabe lembrar o caráter de recusa crítica de Drummond que se pode aferir da leitura do poema-enigma "A máquina do mundo": fazendo eco à opção pelo isolamento como modo de engajamento, o eu diz não à armadilha das luzes e escolhe o impasse como modo de inserção no mundo.

A busca da utópica unidade em meio à inarredável cisão - do homem, da nação, da arte - permite ancorar esse processo na teoria schilleriana da poesia ingênua e sentimental (Shiller, 1991); não estaria Mário, afinal, almejando a arte da espontaneidade, da pureza, do estado anterior à fragmentação do homem moderno? Não se localizaria nessa quimera a mobilização da arte popular como substrato para se pensar o povo brasileiro em sua gênese autêntica desvinculada das fontes civilizadas e importadas? Se a hipótese conferir, a passagem da euforia à melancolia que marca tantos dos escritos do autor - e se irradia por sobre seu percurso como intelectual e artista - se deve à inevitável constatação do caráter "sentimental" da arte moderna, cuja armadilha - em cuja quota de erro reside a honra do fracasso - foi a de se crer a modernidade e a arte passíveis de devolver ao homem a humanidade perdida. O sentido da imitação de um real uno se enraíza na eleição da cultura popular como fonte intocada pela desarmonia incontornável. Ocorre que o estatuto da poesia moderna é avesso à unidade, são palavras de Schiller: "Se o homem entrou no estado de cultura e a arte nele pousou a mão, suprime-se a harmonia sensível, e ele ainda pode se manifestar apenas como unidade moral, ou seja, empenhando-se pela unidade" (ibidem, p.60-1, grifos do autor). A trajetória de Mário cinge-se dessa unidade moral, quimera que orienta a ação inalcançável cuja dor é promessa de felicidade: buscar a unidade é sabê-la irremediavelmente perdida. ${ }^{7}$ Macunaíma, homem-mito, no espaço poético despaisado, petrificado na ordem paradoxalmente esfacelada de uma constelação. Diz dessa presença do sentimental no modo ingênuo, a própria construção da rapsódia Macunaima: miscelânea de referências do populário que, sujeitas ao processo de desnivelamento e nivelamento, ${ }^{8}$ permitem a intervenção de um princípio crítico, negativo e envenenado que trai a exigência de lucidez própria ao modo sentimental. A paulatina constatação da natureza eminentemente ideal dessa busca acaba por turvar as águas que engoliram o boi-totem de Mário em seu poema-testamento A meditação sobre o Tietê: "nas suas águas eu contemplo o boi paciência/ tragado pelas águas parvas do Tietê". $\mathrm{O}$ drama de Mário possivelmente foi o de quem intentou alcançar a ingenuidade para sempre perdida pela via da práxis artística e social - e isso não só na arte como na vida. Não se pense, porém, que o percurso marcado pela ânsia de positividade e harmonia é pleno - a diferença entre a poesia que se quer unidade e não ideal elegíaco de unidade perdida dá a medida de sua utopia: intelectual lúcido, a consciência dos impasses eiva sua obra de crescente melancolia, tingindo de negatividade a euforia utópica perseguida. ${ }^{9}$ 
Nesse sentido, a poesia reflexiva de Drummond atende fortemente àquilo que Schiller denominou de "poesia sentimental", que mira o ingênuo, sabendo-o de antemão perdido, irremediavelmente. ${ }^{10}$ Sob esse prisma, o confronto entre os dois pode ser pensado nesses termos: a negatividade do poeta declaradamente sentimental ofendia a utopia daquele que, sendo inevitavelmente também sentimental, se desejou um ingênuo.

\section{Notas}

I Sobre o diálogo entre Mário de Andrade e Carlos Drummond de Andrade, ver também: Gledson (2003) e Santiago (2002).

2 Segundo João Luiz Lafetá (1986, p.13-16), à fase (ou máscara) do "poeta aplicado", referente a Clã do Jabuti e a Remate de males, sucede a "máscara da diversidade em busca de unidade", período de desequilíbrio e reflexão marcado pela Revolução de 30. Outras duas fases de sua lírica, a saber, a do "espelho sem reflexo", índice da "intimidade atormentada, feita de mutilações e desencontros" e a do "poeta político", marcada pelo protesto advindo da apreensão das questões de classe, trariam a irremediável presença da cisão do sujeito e do mundo.

3 A fase do "poeta aplicado", segundo classificação de João Luiz Lafetá (1986).

4 Refiro-me ao artigo "Do cabotinismo" em Andrade (1972).

5 A reflexão sobre arte moderna e o conceito de autonomia da arte remonta ao livro de Peter Bürger (1993) Teoria da vanguarda. Para o crítico alemão, as vanguardas intentaram a destruição da categoria histórica da autonomia da arte, ao fazer que arte fosse novamente vida. O retorno à vida implicava uma busca da práxis vital emancipada: ruptura com a práxis deteriorada do mundo administrado na busca pela transformação geral do homem. Após a fase dos combates da vanguarda, tal perspectiva foi neutralizada pelo capital, incidindo, perversamente, no seu avesso: a cooptação pelo mercado da obra de arte, agora refém da vida não transformada. Assim, o fracasso das vanguardas implicaria a necessidade de retorno à categoria da autonomia, único refúgio de onde a arte pode resistir.

6 Trata-se da lição de Anatol Rosenfeld em "Reflexões sobre o romance moderno" que, centrada na problemática do romance, pode abranger outras expressões. Segundo o autor, o modo por meio do qual a arte moderna encampa a crise do estatuto da individualidade burguesa é o do retorno ao indiferenciado, às narrativas arquetípicas. Mas caberia acrescentar ao argumento de Rosenfeld a diferença de dicção embutida na retomada: a arte moderna esposará o mito sempre sob o signo da negatividade. Assim, a perda da individualidade burguesa não é recompensada pelo mito, já que este se oferece como um refúgio para sempre malogrado. Haveria também marcas desse retorno ao arquetípico em Drummond sempre, contudo, submetido à impiedosa reflexão. Para Mário, sobretudo na segunda fase de sua lírica, o retorno parece querer ancorar-se aquém da experiência burguesa, daí seu estatuto de arte que se quer ingênua.

7 Diz Anatol Rosenfeld (1973, p.188-9) em "Mário e o cabotinismo": "Seja como for, procurando-a (à sinceridade) perde-se aquela auto-identidade, através do desdobramento diante do espelho da consciência [...]. Infiltra-se então, devido a certos exageros, um momento de pose e artifício que nega a sinceridade e faz duvidar da própria sinceridade da sinceridade. Torná-la, de resto, em princípio importante de um 
movimento já é sintoma de sua perda [...]. a própria exigência da sinceridade é, então, sintoma da crise, ou seja, da cisão e do sentimento de fragmentação".

8 De acordo com a leitura de Gilda de Mello e Souza (2003).

9 Há que pensar o quanto os veios do irracionalismo e do primitivismo, oriundos das vanguardas e incorporados ao modernismo brasileiro, dão voz também ao desejo de encontrar a unidade perdida, diante da humanidade destronada no contexto contemporâneo. Nesse sentido, a libertação do inconsciente configuraria o ápice de um processo tributário de práticas artísticas em torno da valorização do homem natural (que se pense em Gauguin e Cézanne) numa estratégia de afastamento do caráter sentimental da poesia (e da arte), o que permitiria aferir o sentido crítico da opção pela euforia, aventura embriagante dos sentidos, como imersão nos espaços oníricos em busca do princípio do prazer que se faria oposição consciente à cisão, à custa da criação de algo como um espaço poético ingênuo - que, dialeticamente, aos poucos incidiria sobre o projeto de um real transformado pela práxis revolucionária - e não sentimental - isto é, a escolha quimérica de uma "grandeza finita", ingênua, não mais condenada ao ideal melancólico e sentimental de uma "grandeza infinita". Adviria dessa promessa de felicidade, o veio do reencantamento do mundo, encampado por tantos artistas de vanguarda. Para Schiller (1991, p.62), contudo, o caráter de grandeza infinita, ideal, do poeta sentimental é superior ao do ingênuo: "se, ao contrário, se comparam, uma com a outra (a poesia ingênua à sentimental), as próprias espécies, fica patente que a meta pela qual o homem se empenha mediante a cultura é infinitamente preferível àquela que alcança mediante a natureza. Um obtém, portanto, seu valor pelo alcance absoluto de uma grandeza finita; o outro o atinge por aproximação de uma grandeza infinita" (grifos do autor).

10 Davi Arrigucci Jr. (2010) no ensaio “Drummond meditativo" também recorre aos conceitos de Schiller para pensar a poesia de Drummond.

\section{Referências}

ANDRADE, C. D. de. Poesia e prosa. Rio de Janeiro: Nova Aguilar, 1992.

ANDRADE, M. Do cabotinismo. In: O empalhador de passarinho. 3.ed. São Paulo: Livraria Martins Editora, 1972.

O movimento modernista. In: Aspectos da literatura brasileira. 5.ed. São Paulo: Martins, 1974

Poesias completas. Edição crítica de Diléa Zanotto Manfio. Belo Horizonte; Rio de Janeiro: Villa Rica, 1993.

ARRIGUCCI JUNIOR, D. Drummond meditativo, In: Oguardador de segredos: ensaios. São Paulo: Cia. das Letras, 2010.

BÜRGER, P. Teoria da vanguarda. Lisboa: Vega, 1993.

CANDIDO, A. Inquietudes da poesia de Drummond. In: Vários escritos. São Paulo: Duas Cidades, 1995.

DASSIN, J. Politica e poesia em Mário de Andrade. São Paulo: Duas Cidades, 1978. GLEDSON, J. Influências e impasses: Drummond e alguns contemporâneos. São Paulo: Cia. das Letras, 2003. 
LAFETÁ, J. L. Figuração da intimidade: imagens na poesia de Mário de Andrade. São Paulo: Martins Fontes, 1986.

ROSENFELD, A. Mario e o cabotinismo. In: . Texto/Contexto. São Paulo: Perspectiva; Brasília: INL, 1973.

SANTIAGO, S. (Org.) Carlos \& Mário. Correspondência completa entre Carlos Drummond de Andrade (inédita) e Mário de Andrade. Rio de Janeiro: Bem-te-vi, 2002.

SCHILLER, F. Poesia ingênua e sentimental. São Paulo: Iluminuras, 1991.

SOUZA, G. de M. e. O tupi e o alaúde. 2.ed. São Paulo: Edições 34, 2003.

RESUMO - Este ensaio compara, por meio da análise das cartas e poemas de Mário de Andrade e Carlos Drummond de Andrade, aspectos das duas gerações do modernismo brasileiro. Temas como nacionalismo, individualismo, alteridade e concepções sobre arte revelam as continuidades e rupturas entre as duas fases do modernismo no país.

PALAVRAS-CHAVE: Modernismo brasileiro, Mário de Andrade, Carlos Drummond de Andrade, Nacionalismo, Alteridade.

ABSTRACT - This essay compares, through analysis of the letters and poems of Mário de Andrade and Carlos Drummond de Andrade, aspects of two generations of Brazilian Modernism. Themes as nationalism, individualism, otherness and conceptions about art reveal the continuites and ruptures between the two phases of Modernism in the country.

KEYWORDS: Brazilian Modernism, Mário de Andrade, Carlos Drummond de Andrade, Nationalism, Otherness.

Simone Rossinetti Rufinoni é professora de Literatura Brasileira do Departamento de Letras Clássicas e Vernáculas da Faculdade de Filosofia, Letras e Ciências Humanas da USP. @-siruf@hotmail.com

Recebido em 26.3.2013 e aceito em 23.6.2013.

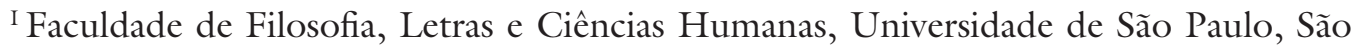
Paulo/SP, Brasil. 